\title{
A Slavonic etymology of Hung. ocsúdik 'to come to, to awake' and the question of the morphological adaptation of Slavonic loan verbs in Hungarian*
}

\author{
MICHAŁ NÉMETH \\ Uniwersytet Jagielloński, Instytut Językoznawstwa, Zakład Filologii Węgierskiej, \\ ul. marsz. Józefa Piłsudskiego 13, PL-31-110 Kraków \\ E-mail: michal.nemeth@gmail.com
}

(Received: 17 December 2014; accepted: 23 March 2015)

\begin{abstract}
The two Turkic etymologies of Hung. ocsúdik (1508) 'to awake, to come to, to regain consciousness' proposed, on the one hand, in the late 19th century by Vámbéry (1870) and, on the other, by K. Palló in 1976 and 1982, have been rightly rejected by the authors of TLH. At the same time, the explanation for the origin of this word found in the etymological dictionaries of Hungarian (TESz, EWUng, Zaicz 2006), namely, that it is a derivative of an unknown unproductive stem, is not entirely convincing for morphological reasons. The present paper offers a new etymology for this word, explaining it as a loanword from East Slavonic очюдитися 'to regain consciousness, to awake' attested in 16th- and 17th-century Russian. The starting point for the discussion is M. Stachowski's (2014) article, in which he compared Hung. ocsúdik with Polish dialectal ocudzić 'to revive'. verbs

Keywords: etymology, Hungarian, Slavonic languages, morphological adaptation, loan
\end{abstract}

1. To date, three attempts have been made to explain the origin of the Hungarian verb ocsúdik 'to awake; to come to' $\sim$ dial. ocsul id. Two of these, which forward the view that the word is of Turkic origin - i.e. Vámbéry's idea to link the Hungarian word with Uyg. otuk 'wakeful, watchful' (VÁmBéRY 1870: 166) and K. Palló's attempt to explain Hung. ocsúdik as a cognate of the Turkic verbal stem ač- 'to open', ačll- 'to be open' (PALló 1976: 339-340, PALló 1982: 141-142) were rightly refuted in TLH (see TLH 2: 1214-1217). Given that the arguments against these two Turkic etymologies sound convincing (additional doubts have been raised in NÉMETH 2015), in the present paper, on the one hand, we would like to present the weak points of the third existing explanation, highlighted in modern etymological dictionaries of Hungarian (i.e. in TESz, EWUng, and ZAICZ 2006), according to which the word is a derivative of an unproductive (and unknown) stem $^{1}$ and, on the other, propose an alternative Slavonic etymology for the analysed word and its dialectal equivalent.

* This article is a slightly modified version of a paper submitted for publication in the journal Magyar Nyelv (NÉMETH 2015).

${ }^{1}$ In another etymological dictionary of Hungarian, the word is mentioned as being of unknown origin, without any further discussion (cf. SzófSz 221). 
2. The word ocsúdik was first attested in Hungarian in 1508 (see e.g. TESz 2: 1066, NádK 593), whereas its dialectal variant, Hung. dial. ocsul, appeared almost two centuries later. The latter was first recorded in 1700 (see e.g. TESz 2: 1066, GYÖNGYÖSI 1763: 20, 30; NySz 3: 1096). In etymological dictionaries of Hungarian (TESz 2: 1066, EWUng 2: 1054, ZAICZ 2006: 583), these two words are interpreted as iterative derivatives built with the suffixes $-d$ and $-l$ from an unproductive stem, and the same opinion is expressed in Benkö's comprehensive work on derivation mechanisms in Hungarian (BENKÖ 1984: 120; only with regard to the verb ocsúdik). ${ }^{2}$ The authors of the above sources admit, however, that the question of whether this hypothetical stem was nominal or verbal must remain open.

The latter doubts arise from the fact that the derivative suffix $-d$ formed iterative verbs from verbs only (evidence of this is already found in early Old Hungarian data), whereas $-l$ was a derivative suffix forming iterative verbs from nominal categories (see e.g. TNyt 1: 83-84, TNyt 2/1: 99, 102). We know that there was still no clear functional distribution between denominal and deverbal derivative suffixes in Old Hungarian but, at the same time, we are aware of no examples of $-d$ forming verbs from nominal categories or of suffix $-l$ forming verbs from verbs. ${ }^{3}$ The fact that there is no convincing explanation for this morphologic discrepancy appears to be an important drawback of the Hungarian etymology.

Another weak point of an etymology based on an internal development model is that the Uralic languages have no potential cognates of the assumed stem ocsú-. ${ }^{4}$ And although the mere fact that Hung. ocsúdik and ocsul have no cognates within the Uralic language family cannot serve as a clear-cut argument against a native etymology, such a form of linguistic isolation becomes a conspicuous shortcoming if we juxtapose it with a morphologically transparent and philologically wellgrounded rival Slavonic etymology.

3. It was Marek Stachowski who first compared Hung. ocsúdik with some Slavonic linguistic data (STACHOWSKI 2014). This idea is not there in Kniezsa's fundamental work on Slavonic loanwords in Hungarian (KNIEZSA 1955), which is important to mention since the latter monograph also includes an exhaustive overview of

\footnotetext{
${ }^{2}$ Given that we know that $-d$ became unproductive in the Old Hungarian period, whereas the productivity of $-l$ was considerably limited at that time and only became important much later, i.e. in the late Old Hungarian period when it played a vital role in the adaptation process of loan verbs (see TNyt 1: 83, 84; TNyt 2/1:68, 82, 96-97), it becomes obvious that the authors of the aforementioned works on Hungarian etymology must have treated both words either as very early loanwords from an unidentified language or, preferably, as an inherited part of the native lexicon.

${ }^{3}$ What we additionally know about these suffixes is that both of them may have been added to irregularly shortened stems. This fact, in turn, proved helpful in developing a feasible native etymology: since there is no native morpheme we know of that could possibly be the basis of such a derivation, assuming an irregularly shortened unknown stem allowed etymologists to ignore any semantic and morphologic restrictions. Such treatment of the facts, however, makes the Hungarian etymology rather more doubtful than feasible.

${ }^{4}$ Obviously, Hung. ocsú 'chaff, husk' cannot be taken into consideration (see TESz 2: 1066 , TLH 2: 626-629). Also scarcely convincing is Budenz's argument that the verbs meaning 'to awake, to wake up' are often of onomatopoeic origin and refer to the "specific sound given forth when someone yawns after waking up" (BUDENZ 1863: 338-339).
}

Studia Slavica Hung. 60, 2015 
dubious etymologies. Stachowski associated the discussed word with Pol. ocucić 'to revive' and wrote the following: "The authors [of TLH - M. N.] rightly dismiss Tkc. $a \check{c}$ - 'to open' as an etymological source of Hung. ocsúdik... In this context, I would like to call attention to another fact: The verb for 'revive' in Polish is ocucić (i.e. with a voiceless [-ucić]). It is only in Southern Poland, certain parts of which (e.g. Orawa) belonged to Hungary in the past, that this verb is pronounced as ocudzić (with voiced [-uźić]), see SEJP [= BorSEJP - M. N.] 88. How do Polish dial. ocudź- and Hung. ocsúd- compare?" (STACHOWSKI 2014: 220).

3.1. Thus, Stachowski draws attention to the fact that Hung. ocsúdik might possibly be etymologically linked to Pol. dial. ocudzić attested in southern Polish dialects. Such an idea is tempting but, at the same time, it is difficult to prove that there is any direct connection between the analysed Hungarian and Polish dialectal word. First of all, even though we find the adduced form ocudzic recorded in the area surrounding Nowy Targ (appr. $90 \mathrm{~km}$ south of Cracow) as well as in the Lublin region (approx. $320 \mathrm{~km}$ north-east of Cracow), it is not recorded in the dialects of the Spisz and Orawa regions, i.e. in territories that once belonged to Hungary contrary to what we read in Stachowski's article (cf. STACHOWSKI 2014: 220). In fact, the form ocudzic is extremely rare in Polish dialects in general (see KarSGP 3: 386, SGP 4: 526-527, FitaK 1997, FitAK 2004, FitaK 2007, Káś 2003, Kąś 2011). Seen in this light, it is rather plausible that the authors of the "Warsaw Dictionary" were right to claim that the voiced palatal affricate in Pol. dial. ocudzić - in lieu of the voiceless palatal affricate in its literary counterpart ocucic - appeared as a result of a blending of Pol. liter. ocucić 'to revive' ocucić się 'to regain consciousness, to come to' with Pol. liter. obudzić 'to wake (up someone), to awake' obudzić się 'to wake (up), to awaken' (see SW 3: 557). And since such a contamination could have taken place in any of the Polish dialects, we cannot really link the form ocudzić either with any specific Polish dialect or with Hung. ocsúdik.

Secondly, if we were to explain the phonetic distance between the - $d$ - in Hung. ocsúdik and -ć- in Pol. ocucić with a Pol. dial. - $\xi^{-}$-, then, in light of the early attestation (i.e. in 1508) of Hung. ocsúdik, we would also need to prove the existence of an ocudzić-like form in Old or Middle Polish. However, no such data can be found in the available historical dictionaries of the Polish language (see SStp 1: 333, s.v. cucenie; SStp 5: 406-407, s.v. ocucenie, ocucić [się]; SStp 7: 108, s.v. przecucić; SPXVI 20: 32-33, s.v. ocucić, ocucić się, ocucony; LiNSJP 2/1: 410, s.v. ocknać; SWil 1: 833), which seems to prove that the possible blend we mentioned above might be of recent origin. But even if we found such a form in Old or Middle Polish, we would need to answer the question of why Pol. $-\dot{z}$ - was adapted in Hungarian as $-d$ - and not as palatal <-gy-> (which would be justly expected here)? If we turn to the Hungarian dialect dictionaries we find two rare forms with palatal <-gy->, namely fölocsógyik and fölocsúgyik (ÚMTsz 2: 382), ${ }^{5}$ but the available historical

\footnotetext{
${ }^{5}$ Let us merely mention that the substitution of Pol. $c$ with Hung. $c$ in the second syllable would not raise doubts since in Polish sources from the 16th-century one can find forms that have $-\check{c}$ - instead of -c- in that syllable: see arch. Pol. oczucić (SPXVI 20: 32-33). But forms like *oczudzić or so were never attested in Polish.
} 
linguistic material shows clearly that these are secondary forms that developed in the Hungarian linguistic environment.

3.2. The idea that Hung. ocsúdik comes directly from Polish dialects also seems hardly likely since we know that the number of Polish loanwords in Hungarian is very small and they are mostly historical terms and nouns, not verbs (see e.g. BÁRCZI 1958: 92-93, TÖRÖK 2007), whereas verbs usually point to a strong linguistic influence. Secondly, we must remember that even the Hungarian loanwords in southern Polish dialects were borrowed mainly via Slovak (see NÉMETH 2009: 10-16) since the boundary between the Hungarian-speaking and Slavonic populations at the time it reached its northernmost point ran along the area inhabited by Slovaks (not Poles) in the Gemer and Malohont region (Hung. Gömör és Kis-Hont, Slk. Región Gemer a Malohont) (see KNIEzSA 1941: 287).

In the case of Hung. ocsúdik and ocsul, we cannot assume Slovak mediation either, since in literary Slovak the etymological counterparts of Pol. ocucić cucić 'to revive' are ocitnút's $a$ 'to come to oneself, to find oneself in an unknown place' and cítit' 'to feel; to scent, to surmise' (see HSSJ 1: 191, HSSJ 3: 108, SSJ 1: 173174 ) and there is no Slovak dialectal form that would contain $-u$ - instead of $-i$ - in the first syllable and which would also explain the presence of $-d$ - in Hungarian. ${ }^{6}$ Due to the Hungarian administration and education, the number of direct Hungarian loans in Polish dialects increased from the end of the 18th century but this influence was not reciprocal: the number of Polish loanwords in Hungarian did not rise at all.

3.3. Finally, for similar phonetic and historical-geographical reasons, it would also be difficult to defend the view that Pol. dial. ocudzić comes from Hung. ocsúdik.

4. Let us, however, present the relevant Slavonic linguistic material in a broader perspective.

4.1. The Pol. ocucic is a reflex of PSlav. *otjutiti 'to sense again, to regain consciousness' < prep. *ot $+*$ jutiti 'to feel, to sense, to perceive' (see ÈSRJa 3: 179, s.v. oчyтиться, SłSEJP 1: 108, s.v. cucić, BorSEJP 379, s.v. ocucić, or DERKSEN 2008: 381$).^{7}$ The word initial $o$ - has been dropped in a number of Slavonic languages. The reason for this apheresis was that the morphological boundaries have been blurred (cf. $*^{*} o t+*_{j-}>o c-, o \check{c}_{-}, o c^{-}, o \check{s} t-$, etc.) and the relevant verbs have been reinterpreted as $o$ - prepositional forms. This took place not only in Polish (cf. Pol. ocucić cucić) but also in Czech, Slovak, and the South Slavonic languages (in the latter case, however, forms with $o$ - are much rarer), see e.g. OCz. cútiti, Cz. cítit 'to feel, to sense', Ocz. octnúti sě, Cz. oc(i)tnouti se 'to regain consciousness, to find oneself in an unknown place', Slk. cítit' 'to feel; to sense, to surmise', ocitnút' sa 'to come to, to find oneself in an unknown place', Cr. ćutjeti, oćutjeti 'to feel', oćućivati ‘(iter.) to feel' (see e.g. МАснEK 1968: 87-88, s.v. cítiti;

\footnotetext{
${ }^{6}$ The author of the present paper has referred to over forty dictionaries devoted to the Slovak literary language and dialects (for instance, to mention the most relevant ones, SSJ 2: 468, BAKOŠ 1994, KRET 1994, FeKETE 1995, HABOVŠTIAK 1995, HodOROVSKÝ 1997, VS 2002, JELEŇOVÁ 2011). I would like to thank Dr. hab. Zbigniew Babik (Kraków) for providing me with access to the Slovak dialect dictionaries.

${ }^{7}$ We have to wait for volumes that will possibly contain the lemma *otjutiti in ÈSSJa and SłPsł. 
SS 4: 255, HSSJ 1: 191, HSSJ 3: 108, RHiSJ 8: 535, 536-537; ERHiSJ 1: 367368 , s.v. ćutjeti). Ukrainian contains no example of this apheresis; the dictionaries of this language only record очутитися ' 1 . to come to, to regain consciousness; 2. to regain the poise of mind' (see e.g. SUM 5: 836; at the same time, the word is not recorded in SSuM).

But all the above-mentioned forms must be dismissed as possible etymons of Hung. ocsúdik, and for the same reason as with the case of Pol. ocucić $\sim$ Pol. dial. ocudzić: the Hungarian word-medial $-d$ - cannot be explained by either of them. There is, however, one form that seems to be a perfect candidate for the etymon of Hung. ocsúdik as its phonetic shape and meaning is very close to it: in 16thand 17th-century Russian, we can find the verb очюдитися 'to come to, to regain consciousness; 2. to wake up; 3 . to get somewhere' attested, which is an alternant of Russ. очутитися очютитися used also in the 16th and 17th centuries (see SRJaXI-XVII 14: 105-106). The present-day Russian equivalent of these is ouyтиться 'to turn up, to find oneself in an unknown place'.

Obviously, ESlav. очюдитися is a mediopassive derivative of the 16th- and 17th-century Russ. очутити очютити ' 1 . to feel; 2 . to notice; 3 . to understand' (SRJaXI-XVII 14: 105-106) and, in fact, Hung. ocsúdik might possibly originate from both очюдитися and *очюдити. But the mediopassive form seems to be a somewhat more probable etymon considering its meaning (cf. next chapter).

4.2. At this point, we should mention that identifying the Slavonic morphological boundaries and, as a next step, disjoining the Slavonic infinitive ending (-iti or -iti sja) and replacing it with a Hungarian derivative suffix is a quite wellknown phenomenon in Hungarian (see, however, our additional remarks below in 5.1). Moreover, the mediopassive character of Hung. ocsúdik (cf. the ending -ik) accords with the mediopassive voice of the adduced Slavonic etymon. Importantly, the suffix -ik was still a productive marker of the mediopassive voice in the late Old Hungarian period (i.e. in the late 15th and in the early 16th centuries) (see MNyt 2/1: 217).

5.1. Thus, it transpires from the above that nothing can be faulted as far as the East Slavonic etymology of Hung. ocsúdik is concerned - at least from a phonetic and semantic point of view. There is, however, one factor which forces us to treat this explanation somewhat cautiously. Slavonic loan verbs that entered Hungarian usually received the derivative suffix $-l$ (see e.g. TNyt 2/1: 49) or the derivative suffix $-z$ if the verb joined the $-i k$ conjugation (see RónA-TAS 2010: 39 ). This is the way verbs were usually adapted in the Hungarian linguistic environment - with the exception of a number of Old Turkic loan verbs that entered Hungarian very early without any additional morphemes (see RóNA-TAS 2010: 40-41). We have the suffix $-l$ in ocsul but it is a much younger form and provides no explanation for the structure of ocsúdik. Recent research proves that the presence or absence of additional derivative suffixes in loan verbs depends on the age of the borrowing process (the older a word is, the more likely it is that it was loaned without additional derivative suffixes attached). There are also a few verbs of Slavonic origin that belong to this group (dominated by Old Turkic loanwords). However, none 
of these Slavonic verbs dates from after 1508, see: Slav. *měriti 'to measure' > Hung. (after 1372 /around 1448) mér id. and ESlav. *styditi 'to defame, to shame' > Hung. szid (around 1315) 'to reprimand' (see ZolTÁn 2014: 212, TESz 3: 747, TESz 2: 897). The latter parallel example is all the more informative as its East Slavonic origin (similar to what might be the case regarding ocsúdik) has been proved by András Zoltán: the meaning 'to defame, to shame' is attested only in that group of Slavonic languages (ZOLTÁN 1999: 58). ${ }^{8}$

5.2. Perhaps, however, a good explanation would be to treat Hung. ocsúdik as an early loanword, too? Even though ocsúdik first appeared in Hungarian written sources much later than the two parallel examples, we must remember that the date of a word's first attestation does not mean that it was not used earlier. Treating it as a somewhat older loanword would explain the absence of the expected derivative suffix.

5.3. On the other hand, another explanation would be to assume that this type of adaptation process may occasionally have taken place later, at least by the beginning of the 16th century.

5.4. What makes the Slavonic etymology of Hung. ocsúdik convincing - besides the phonetic and semantic conformity - is that we do not have to treat the word medial $-d$ - as a derivative suffix (cf. the doubts mentioned above in chapter 2) but as part of a Slavonic stem and that it has a transparent Slavonic philological background.

6. However, this etymology does not answer the question of how Hung. ocsúdik and Hung. dial. ocsul compare. This is because we cannot explain the latter as a loanword from the ESlav. *očuditi * očutiti. In other words, ocsúdik and ocsul cannot be treated as etymological doublets.

We know that ocsul is a much more recent and rarer form - this transpires clearly from the historical and the dialectal linguistic data (see e.g. OklSz, NySz, SzT, TESz, etc.). In fact, in ÚMTsz, we find only one example of its use (ÚMTsz 3: 346, ÚMTsz 4: 159), whereas in MTsz, it is not recorded at all (MTsz 2: 1569). Seen in this light, it seems very likely that ocsul emerged from ocsúdik within Hungarian thanks to a misinterpretation of the morphological boundaries and the replacement of $-d$ - (believed to be a derivative suffix) with $-l$ (which can be added to irregularly shortened stems, too). Perhaps, this happened by way of analogy to vajúdik (around 1456) '1. to feel the want of, to need; 2 . to get tired, to weaken; 3 . to be in labour (with child), to be in parturiency' alternating with vajul (15671576) ' 1 . to get tired, to weaken; 2 . to be in labour (with child), to be in parturiency' (TESz 3: 1071).

7. The general outline of the proposed etymology looks, therefore, as follows: ESlav. *očuditi sja (cf. Russ. очюдитися) 'to come to, to regain consciousness; to wake up' > Hung. ocsúdik 'to awake, to come to, to regain consciousness' $\rightarrow$ Hung. dial. (rare) ocsul 'id.' (by way of analogy to vajúdik $\sim$ vajul).

\footnotetext{
${ }^{8}$ In the case of *merriti, there is no criterion for determining the answer for the question which group of Slavonic languages the word originates from in Hungarian.
}

Studia Slavica Hung. 60, 2015 


\section{Abbreviations and symbols}

arch. $=$ archaic Cr. = Croatian; Cz. = Czech; dial. = dialectal; ESlav. = East Slavonic; Hung. = Hungarian; iter. = iterative; liter. = literary; Pol. = Polish; OCz. = Old Czech; PSlav. $=$ Proto-Slavonic $;$ Slav. $=$ Slavonic $;$ Slk. $=$ Slovak $;$ Tkc. $=$ Turkic $;$ Uyg. $=$ Uyghur; $\|>,<=$ borrowing; $\rightarrow=$ morphological development; $<$ abc $>=$ orthographic notation.

\section{References}

BAKOŠ 1994 = BAKOŠ Samko: Krátky slovník nárečia slovenského Gemerského. RybníkBratislava: Print-Servis, 1994.

BÁrCZI 1958 = BÁRCZI Géza: A magyar szókincs eredete . Budapest: Tankönyvkiadó, 1958.

BENKÖ 1984 = BENKÖ Loránd: A magyar fiktív (passzív) tövü igék. Budapest: Akadémiai Kiadó, 1984.

BorSEJP = BORYŚ Wiesław: Stownik etymologiczny języka polskiego. Kraków: Wydawnictwo Literackie, 2005.

BudENZ 1863 = BuDENZ József: A török hangutánzó igékröl. Nyelvtudományi Közlemények 2 (1863): 338-361.

DERKSEN 2008 = DERKSEN Rick: Etymological Dictionary of the Slavic Inherited Lexicon. Leiden-Boston: Brill, 2008.

ERHiSJ = SKOK Petar: Etimologijski rječnik hrvatskoga ili srpskoga jezika. Knj. 1-4. Zagreb: Jugoslavenska akademija znanosti i umjetnosti, 1971-1974.

ÈSRJa = ФАСмЕР Макс: Этимологический словарь русского языка. Т. 1-4. Москва: «Прогресс», 1986-1987.

ÈSSJa = ТРУБАЧЕВ О. Н., ЖУРАВЛЕВ А. Ф. (ред.) Этимологический словарь славянских языков. Праславянский лексический фонд. Т. 1-39. Москва: «Наука», 1974-2014.

EWUng = BENKÖ Loránd et al. (szerk.): Etymologisches Wörterbuch des Ungarischen . Bd. 1-2. Budapest: Akadémiai Kiadó, 1993-1995.

FEKETE 1995 = FEKETE Ján: Krátky slovník nárečia slovenského Modrokamenského. Modrý Kameň: Print-Servis, 1995.

FITAK 1997 = FITAK Franciszek: Stownik gwary orawskiej. Gliwice: RMR, 1997.

FITAK 2004 = FITAK Franciszek: Słownik gwary spiskiej. Szczawnica: Ośrodek Kultury Turystyki Górskiej PTTK w Pieninach, 2004.

FITAK 2007 = FITAK Franciszek: Gwara podhalańska, orawska i spiska. Stownictwo wybrane. Szczawnica: Ośrodek Kultury Turystyki Górskiej PTTK w Pieninach, 2007.

GYÖNGYÖSI 1763 = GYÖNGYÖSI István: Uj életre hozatott Chariclia, avagy a Chariclia ritka példájú, és olvasásra kedvet adó historiának némelly régi versek rongyábúl, és azoknak sok fogyatkozásibul ujjabb, és jobb rendben vétele. Buda: Landerer Ferenc Leopold, 1763 [non vidi].

HABOVŠTIAK 1995 = HABOVŠTIAK Anton: Krátky slovník nárečia slovenského Oravského. Krivá-Bratislava: Print-Servis, 1995.

HodOROvSKÝ 1997 = HodOROvsKÝ Jozef: Malý Spišský slovník. Spišská Nová Ves: Mesto Spišská Nová Ves, 1997.

HSSJ = MAJTÁN Milan (red.): Historický slovník slovenského jazyka 1-6. Bratislava: Veda, 1991-2005.

JELEŇOVÁ 2011 = JELEŇOVÁ Darina: Novol'ubovniansky goralský nárečový slovník. Novol’ubovniansko-slovenský a slovensko-novol'ubovniansky. [s. 1.], 2011. 
KarSGP = KARŁOwICZ Jan: Stownik gwar polskich 1-6. Kraków: Polska Akademia Umiejętności, 1900-1911.

KĄŚ 2003 = KĄŚ Józef: Słownik gwary orawskiej. Kraków: Księgarnia Akademicka, 2003.

KĄŚ 2011 = KĄŚ Józef: Stownik gwary orawskiej 1-2. Kraków: Księgarnia Akademicka, 2011.

KNIEZSA 1941 = KNIEZSA István: Zur Geschichte der ungarisch-slowakischen ethnischen Grenze. Archivum Europae Centro-Orientalis 7 (1941): 240-309.

KNIEZSA 1955 = KNIEZSA István: A magyar nyelv szláv jövevényszavai 1/1-2. Budapest: Akadémiai Kiadó, 1955.

KRET 1994 = KRET Anton: Krátky slovník nárečia slovenského Spišského. Spišská Nová Ves-Smižany-Bratislava: Print-Servis, 1994.

LinSJP = LindE Samuel Bogumił: Słownik języka polskiego 1-6. Lwów: Drukarnia XX. Piiarów, 1807-1814.

MACHEK 1968 = MACHEK Václav: Etymologický slovník jazyka českého. Praha: Československá akademie věd, 1968.

MTsz = SzINNYEI József (szerk.): Magyar tájszótár 1-2. Budapest: Hornyánszky Viktor Akadémiai Könyvkereskedése, 1893-1901. [Facsimile edition: Budapest: Nap, 2003].

NádK = PUSZTAI István (szerk.): Nádor-kódex (1508). A nyelvemlék hasonmása és betühü átirata bevezetéssel és jegyzetekkel. (Régi Magyar Kódexek 16.) Budapest: Magyar Nyelvtudományi Társaság, 1994.

NÉMETH 2009 = NÉMETH Michał: Zapożyczenia węgierskie $w$ gwarze orawskiej i drogi ich przenikania. Kraków: Księgarnia Akademicka, 2009.

NÉMETH 2015 = NÉMETH Michał: Az ocsúdik ige etimológiája szlavisztikai megközelítésben. Magyar Nyelv 111 (2015) [In press.]

NySz = SZARVAS Gábor, SIMONYI Zsigmond: Magyar nyelvtörténeti szótár a legrégibb nyelvemlékektöl a nyelvújításig 1-3. Budapest: Hornyánszky Viktor Akadémiai Könyvkereskedése, 1890-1893.

OklSz = SzAMOTA István, ZoLNAI Gyula (szerk.): Magyar oklevél-szótár. Régi oklevelekben és egyéb iratokban elöforduló magyar szók gyüjteménye. Pótlék a Magyar nyelvtörténeti szótárhoz. Budapest: Hornyánszky Viktor akadémiai könyvkereskedése, 1902 1906. [Facsimile edition: Budapest: Állami Könyvterjesztő Vállalat, 1984].

PALló 1976 = K. PALló Margit: Ocsúdik. Magyar Nyelv 72 (1976): 339-340.

PALló 1982 = K. PALló Margit: Régi török eredetü igéink. (Studia Uralo-Altaica 1.) Szeged: József Attila Tudományegyetem, 1982.

RHiSJ = DANIČIĆ Đuro, MARETIĆ Tomo: Rječnik hrvatskoga ili srpskoga jezika. Knj. 1-23. Zagreb: Jugoslavenska akademija znanosti i umjetnosti, 1880-1976.

RÓNA-TAS $2010=$ RÓNA-TAS András: Morphological embedding of Turkic verbal bases in Hungarian. In: JohANsON Lars, RobBEETs Martine (eds.): Transeurasian Verbal Morphology in a Comparative Perspective: Genealogy, Contact, Chance. (Turcologica 78.) Wiesbaden: Harrassowitz, 2010. 33-42.

SGP = KARAŚ Mieczysław, REICHAN Jerzy, OKONIOwA Joanna (red.): Słownik gwar polskich 1-8. Kraków: Instytut Języka Polskiego Polskiej Akademii Nauk, 1979-2013.

SłSEJP = SŁAWSKI Franciszek: Stownik etymologiczny języka polskiego 1-6. Kraków: Towarzystwo Miłośników Języka Polskiego, 1952-1975.

SłPsł = SŁAWSKI Franciszek (red.): Słownik prasłowiański 1-8. Wrocław-Warszawa-Kraków: Wydawnictwo Polskiej Akademii Nauk, 1974-2001.

SPXVI = BĄK Stanisław (red.): Stownik polszczyzny XVI wieku 1-36. Wrocław-WarszawaKraków: Wydawnictwo Polskiej Akademii Nauk, 1966-2014. 
SRJaXI-XVII = Словарь русского языка XI-XVII вв. 1-28. Москва: «Наука», 19752008.

SS = HAVRÁNEK Bohuslav, KŘísteK Václav, PETR Jan (red.): Staročeský slovník 1-26. Praha: Academia, 1968-2008.

SSuM = ГУМЕЦЬКА Л. Л., КЕРНИЦЬКИЙ І. М. (ред.) Словник староукраӥнської мови $X I V-X V$ cm. Т. 1-2. Київ: «Наукова думка», 1977-1978.

SSJ = PECIAR Štefan (red.): Slovník slovenského jazyka 1-6. Bratislava: Vydavatel'stvo SAV, 1959-1968.

SStp = URBAŃCZYK Stanisław (red.): Stownik staropolski 1-11. Warszawa: Instytut Języka Polskiego Polskiej Akademii Nauk, 1953-2002.

STACHOWSKI 2014 = STACHOWSKI Marek: Remarks on the investigation of the oldest layer of Turkic loanwords in Hungarian. Studia Etymologica Cracoviensia 19 (2014): 215222.

SUM = БІлодІд I. К. (ред.) Словник украӥнської мови 1-11. Київ: «Наукова думка», 1970-1980.

SWil = Stownik języka polskiego 1-2. Wilno: Orgelbrand Maurycy, 1861.

SzófSz = BÁRCZI Géza: Magyar szófejtő szótár [1941]. Budapest: Trezor, 1994.

SzT = SzABó T. Attila, VÁMSzer Márta, KósA Ferenc (szerk.): Erdélyi magyar szótörténeti tár 1-12. Bucureşti: Kriterion, Budapest: Akadémiai Kiadó, Cluj-Napoca: Erdélyi Múzeum-Egyesület, 1975-2005.

TESz = BENKŐ Loránd et al. (szerk.): A magyar nyelv történeti-etimológiai szótára 1-3. Budapest: Akadémiai Kiadó, 1967-1976.

TLH = BERTA Árpád, RÓNA-TAS András: West Old Turkic. Turkic Loanwords in Hungarian 1-2. (Turcologica 84.) Wiesbaden: Harrassowitz, 2011.

TNyt = BENKÖ Loránd (szerk.): A magyar nyelv történeti nyelvtana 1: A korai ómagyar kor és elözményei; 2/1: A kései ómagyar kor. Morfematika; 2/2: A kései ómagyar kor. Mondattan. Szöveggrammatika. Budapest: Akadémiai Kiadó, 1991-1995.

TÖRÖK 2007 = TÖRÖK Katalin: Polonizmy w języku węgierskim. Prace Filologiczne 53 (2007): 629-636.

ÚMTsz = LÖRINCZY Éva (szerk.): Új magyar tájszótár 1-5. Budapest: Akadémiai Kiadó, 1979-2010.

VÁMBÉRY 1870 = VÁMBÉRY Ármin: Magyar és török-tatár szóegyezések. Nyelvtudományi Közlemények 8 (1870): 109-189.

VS 2002 = HALAGA Ondrej Richard: Východnoslovenský slovník 1-2. Košice-Prešov: Universum, 2002.

ZAICZ 2006 = ZAICZ Gábor (szerk.): Etimológiai szótár. Magyar szavak és toldalékok eredete. Budapest: Tinta, 2006.

ZOLTÁN 1999 = ZOLTÁN András: „Lappangó” szláv eredetü szavaink: szid, szégyen. Magyar Nyelv 95 (1999): 54-59.

ZoLTÁn 2014 = ZoLTÁN András: Einige Bemerkungen zu Luubor Králiks slawischer Etymologie von ung. vizsga, vizsgál. Studia Etymologica Cracoviensia 19 (2014): 211-213. 